\title{
Success Rate of Left Varicocele Embolization in Management Recurrent Varicocele after Surgery
}

\author{
HAYTHAM MOHAMED NASSER, M.D.* and HATEM SAYED, M.D.** \\ The Departments of Radiology* and General Surgery**, Faculty of Medicine, Ain Shams University
}

\begin{abstract}
Background: Varicoceles dilation of veins are present in $15 \%$ of men. Varicocele can be asymptomatic or symptomatic. Symptoms include pain and/or infertility. Varicocele recurrence depend mainly on the used technique for repair. The recurrence rate ranges from $1.05-14.97 \%$.
\end{abstract}

Aim of Study: The purpose of this study is to measure the success rate of the embolization technique in patients with recurrent left symptomatic varicocele after surgery.

Patients and Methods: This cross sectional study included 15 patients with symptomatic (pain or infertility) recurrent left varicocele after surgery. Embolization was done at Ain Shams University hospitals from October 2017 to December 2018.

Results: Varicocele embolization for recurrent varicocele after surgery has technical success of $93.3 \%$.

Conclusion: Embolization is an effective way to treat recurrent varicocele after surgery.

Key Words: Varicocele $(V C)$ - Gonadal Vein $(G V)-$ Butyl Cyanoacrylate (BC) - Primary Infertility (PI) Percutaneous Embolization (PE).

\section{Introduction}

A VARICOCELE is composed of dilated veins within the spermatic cord [1]. Both surgical and nonsurgical methods are used to treat varicocele. Varicocele recurrence depends mainly on the technique used with recurrence rate ranging from 1.05 $14.97 \%$ [2] . Recurrence of varicocele could cause recurrent symptoms including scrotal pain and/or infertility.

Surgical failure rate may be due to pre-existing venous collaterals causing recurrence. Surgery or percutaneous varicocele embolization are different options to treat recurrence. However, percutaneous embolization is superior to surgery as it can identify gonadal vein variants. The use of venography is

Correspondence to: Dr. Haytham Mohamed Nasser, E-Mail: Hmnh1980@gmail.com crucial to identify these collaterals and successfully eliminate them [3-4].

Percutaneous varicocele embolization is a minimally invasive technique with much lower complications compared to surgery and with the advantage of local anaesthesia instead of general anaesthesia [5].

Aim of work:

The aim of this study is to measure the success rate of the embolization technique in recurrent symptomatic left sided varicocele after surgery.

\section{Patients and Methods}

\section{Patients:}

This study included 15 patients. All patients have symptomatic left sided recurrent varicocele after surgery within a period of 6 months to 24 months. Diagnosis is confirmed using U/S and duplex to confirm reflux. 8 patient complained from recurrent scrotal pain and 7 patients complained of infertility. Semen analysis in those 7 patients, in which 3 patients with low number only, 4 patients with low motility.

All patients underwent left sided varicocele embolization using Histoacryl, we failed to catheterize one patient to do venography or embolization likely due to venous anatomy variation.

\section{Inclusion criteria:}

- Patients with left recurrent varicocele after surgery diagnosed by U/S and confirmed during the operation with venography.

- No age prediliction.

Exclusion criteria:

- Bleeding tendency.

- Any contraindication to the injection of contrast: High serum creatinine or allergy. 


\section{Ethical consideration:}

An informed consent is obtained from the patient concerning the complication of the procedure, the complication of the glue and the acceptance to be enrolled in the study.

\section{Statistical analysis:}

Data were coded and entered using the statistical package SPSS (Statistical Package for the Social Sciences) version 23.

The 15 patients enrolled in this study were ranging from 20 to 42 years with mean age of 35.6 years.

Table (1): Representing the statistical data analysis for different ages enrolled at our study.

\begin{tabular}{ll}
\hline Age (years) & No. $=15$ \\
\hline Mean \pm SD & $35.60 \pm 4.61$ \\
Range & $20-42$ \\
Age $<30$ & $10(66.7 \%)$ \\
Age $>30$ & $5(33.3 \%)$ \\
\hline
\end{tabular}

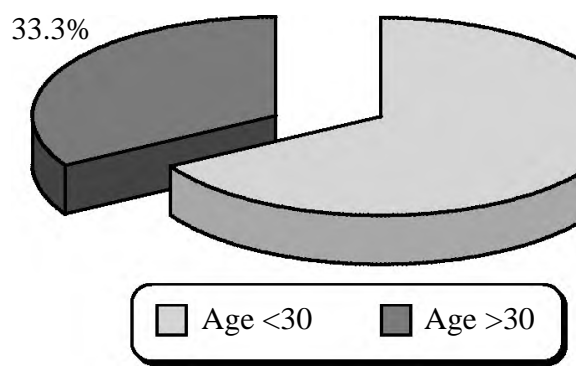

Diagram (1): Showing that in our study 10 patients were less than 30 years $(66.7 \%)$, and 5 patients were 30 years and above $(33.3 \%)$.

\section{Presenting complain:}

7 patients presented with recurrent infertility and 8 patients presented with recurrent scrotal pain.

Table (2): Demonstrating statistical analysis as regard the clinical indication for varicocele embolization.

\begin{tabular}{lcc}
\hline Presenting complain & No. & $\%$ \\
\hline Pain & 8 & 53.3 \\
Recurrent Infertility & 7 & 46.7 \\
\hline
\end{tabular}

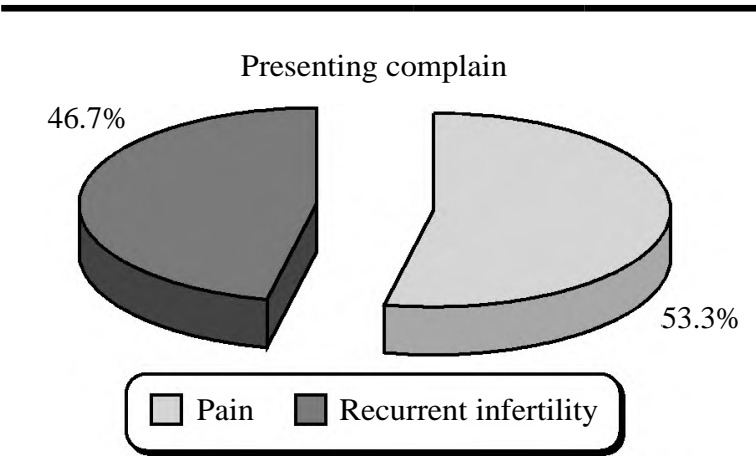

Diagram (2): Representing the percentage of patient with recurrent pain $(53.3 \%)$, and recurrent infertility $(46.7 \%)$.

\section{By imaging aassessment:}

All patients were examined by U/S, the examination revealed, all of them had left recurrent varicocele.

\section{Semen analysis:}

3 patients showed decreased number and 4 patients had decreased motility.

Table (3): Demonstrating the statistical data for patients presented with recurrent infertility, 3 had low number $(20 \%)$ and 4 had low motility $(26.7 \%)$.

\begin{tabular}{cc}
\hline & No.=7 \\
\hline Low number & $3(20.0 \%)$ \\
Low motility & $4(26.7 \%)$ \\
\hline
\end{tabular}

Table (4): Concerning the complications occurred.

\begin{tabular}{cll}
\hline & No. & $\%$ \\
\hline Complications: & & \\
No & 10 & 66.7 \\
Yes & 5 & 33.3 \\
Pain & 5 & 33.3 \\
\hline
\end{tabular}

It occurred in 5 case $(33.3 \%)$ in the form of self limited hypochondrial pain after the procedure for one week that resolved over analgesics.

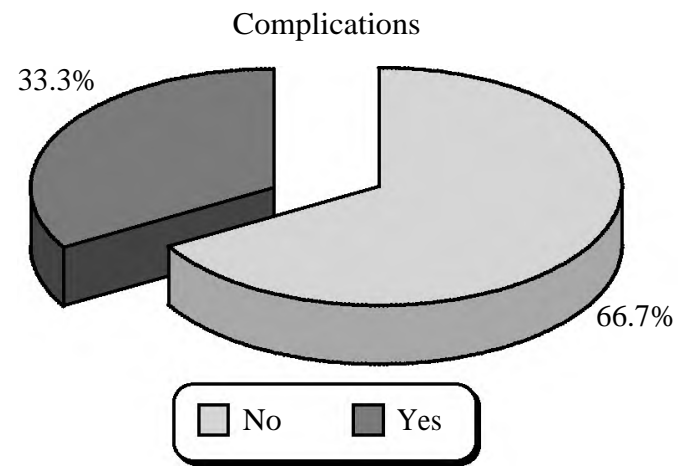

Diagram (3): Showing patients' percentage with and without complications.

Table (5): Causes of recurrence after surgery in our study according to Bähren classification of left varicoceles.

\begin{tabular}{lcc}
\hline $\begin{array}{l}\text { Causes of recurrence as } \\
\text { identified by venography }\end{array}$ & No. & $\%$ \\
\hline Type III duplication & 10 & 66.7 \\
Type II & 2 & 13.3 \\
Type IV & 1 & 6.7 \\
Type V & 1 & 6.7 \\
\hline
\end{tabular}



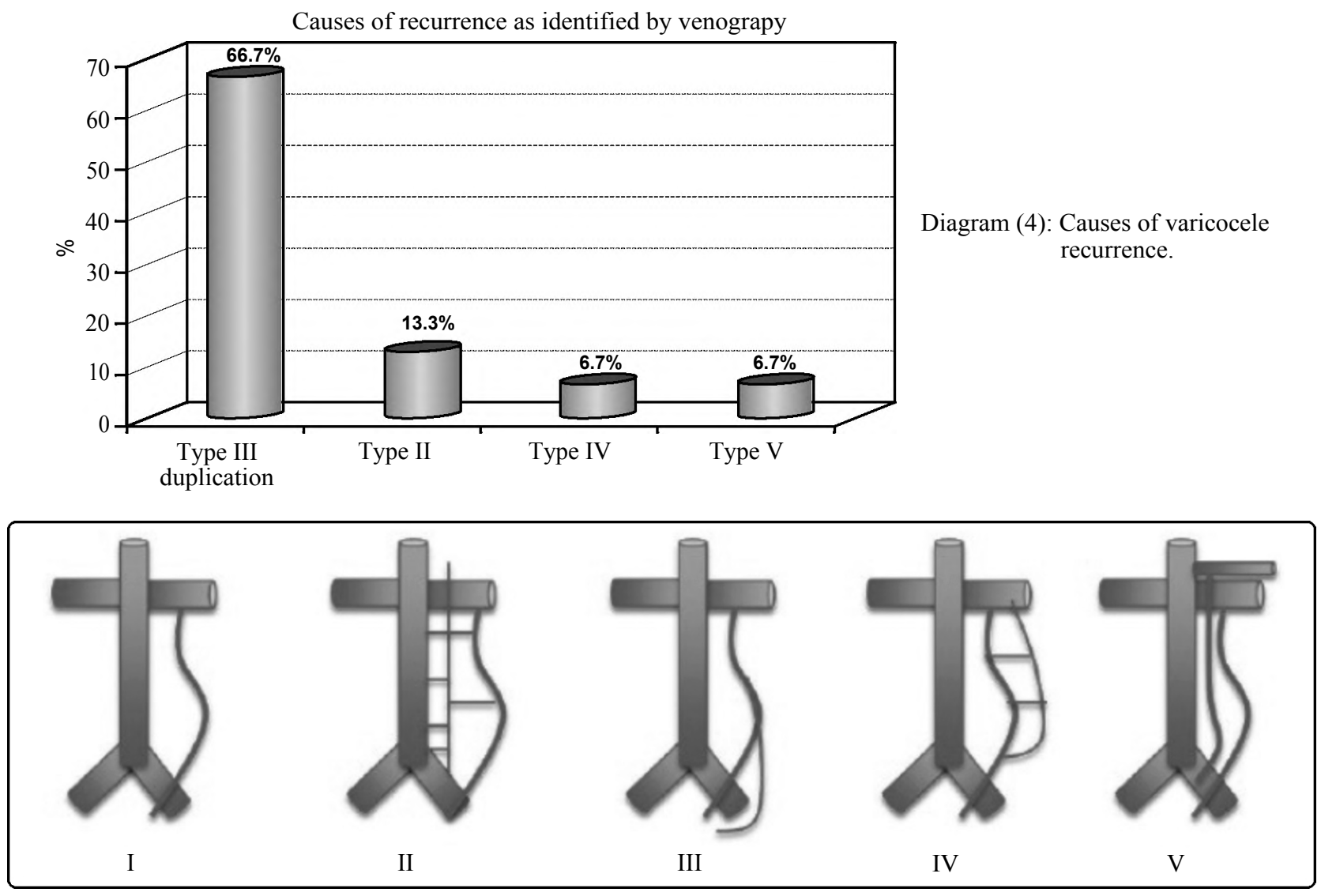

Diagram (5): Schematic of B ähren et al. [6] classification of types of varicocele, published in 1983.

\section{Bähren classification of left varicoceles [6]:}

- Type 0: No evidence of venous reflux in internal spermatic vein (ISV)

- Type I: Single ISV with insufficient or absent valve

- Type II: Single ISV with >_ 2 ostia to renal vein; may be branches to ascending lumbar / retroperitoneal veins:

- IIa: Insufficient confluence valve function

- IIb: Sufficient confluence valve function

- Type III: Single incompetent ISV at renal vein junction, with caudal duplication

- Type IV: Valveless collaterals between ISV and segmental renal/retroperitoneal veins:

- IVa: Insufficient confluence valve.

- IVb: sufficient confluence valve function.

- Type V: IVC or renal vein anomaly; ISV may enter IVC/renal/ascending lumbar veins.

Table (6): Shows technical success rate.

\begin{tabular}{lc}
\hline & Technical success of the embolization procedure \\
\hline Succeeded & $14(93.33 \%)$ \\
Failed & $1(6.67 \%)$ \\
\hline
\end{tabular}

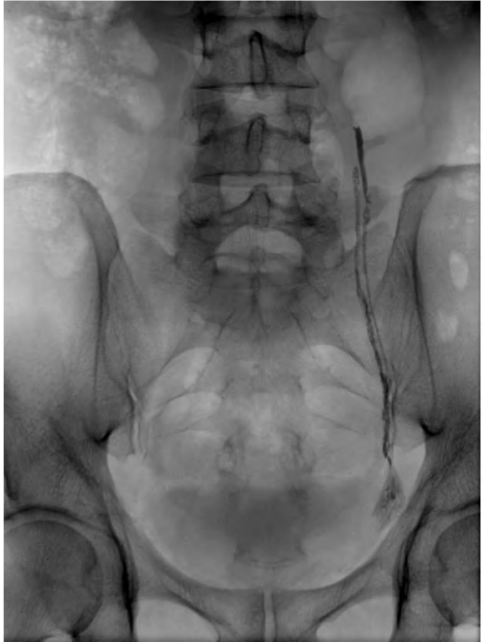

Image (1): Showing histoacryl cast in duplicated caudal left ISV type III B ähren most command type of recurrence in our study.

\section{Discussion}

Varicocele treatment options continue to evolve over time, one of the main choices now is percutaneous varicocele embolization which is a minimally invasive technique requiring only local anaesthesia and interventional radiology expertise with minimum complications [7]. 
In our study, 15 patients had left varicocele recurrence after surgery within a period of 6-24 months after the surgery. By ultrasound examination, left sided varicocele with reflux was identified.

Although varicocele embolization may be equivalent to surgery in primary varicocele patients, but varicocele embolization after surgical failure is the most appropriate option. During varicocele embolization, venography is done to confirm reflux as well as to identify the cause of failure by precisely identifying collateral veins causing reflux [8].

In our study, 15 patients were enrolled with varicocele recurrence after surgical failure, our left side emolization technical success was $93.3 \%$. this is comparable with Badar et al., when he mentioned that varicocele embolization technical success rate after surgical failure is extremely high ranging from $93 \%$ to $100 \%$ [9].

Jargiello et al., 2015 also agreed with us when he mentioned that when varicocele recurs, endovascular treatment is still performed via a retrograde way by accessing the left gonadal vein via the left renal vein, either from a right internal jugular or right femoral vein approach with $100 \%$ technical success [3].

In our study, according to venography $66.7 \%$ are identified to have Type III collateral according to Bähren classification, 13.3 had type II and IV and $6.7 \%$ had type V. Jargiello et al., 2015, agreed with us when he mentioned that $66 \%$ of his patients had Type III venography [3].

In our study, as regard post procedural complications: 5 of our 15 patients had hypochondrial pain related to the site of gonadal vein embolization that last from 5 days to week that was controlled with analgesics.

Nabi et al., 2004 agreed with our rates of complications as he mentioned that the complications of percutaneous therapy are infrequent and typically mild Complication rates in recent literature have been reported from $0 \%$, to $5 \%$ and $11 \%$ [10].

\section{Limitations of the study:}

A limitation of this study is relative small sample size. We recommend larger multicenter comparative study with larger sample size.

\section{Conclusion:}

Embolization is an effective way to treat recurrent varicocele after surgery where venography done during varicocele embolization is crucial to identify and embolize collaterals which is the cause of recurrence.

\section{References}

1- WEIN A.J., KAVOUSSI L.R., CAMPBELL M.F., editors.: Campbell Walsh Urology. Philadelphia, PA: Elsevier Saunders, 2012

2- CAYAN S., SHAVAKHABOV S. and KADIOGLU A.: Treatment of palpablevaricocele in infertile men: A metaanalysis to define the besttechnique. J. Androl., 30 (1): 33-40, 2009.

3- JARGIELLO T., DRELICH-ZBROJA A., FALKOWSKI A., SOJKA M., PYRA K. and SZCZERBO-TROJANOWSKA M.: Endovascular transcatheterembolization of recurrent postsurgical varicocele: Anatomic reasonsfor surgical failure. Acta. Radiol., 56 (1): 63-9, 2015.

4- MOON K.H., CHO S.J., KIM K.S., PARK S. and PARK S.: Recurrent Varicoceles: Causes and Treatment Using Angiography andMagnification Assisted Subinguinal Varicocelectomy. Yonsei Med. J., 53 (4): 723-8, 2012.

5- TANRIKUT C., McQUAID J.W. and GOLDSTEIN M. The impact of varicocele and varicocele repair on serum testosterone. Curr. Opin. Obstet. Gynecol., 23: 227-3 1, 2011.

6- BÄHREN W., LENZ M., PORST H. and WIERSCHIN W.: Side effects, complications and contraindications for percutaneous sclerotherapy of the internal spermatic vein in the treatment of idiopathic varicocele. Rofo., 138: 1729,1983 .

7- TROMBETTA C., LIGUORI G., BUCCI S., CICILIATO S. and BELGRANO E.: Percutaneous treatment of varicocele, Urol. Int., 70 (2): 113-8, 2003.

8- GAT Y., ZUKERMAN Z., CHAKRABORTY J. and GORNISH M.: Varicocele, hypoxia and maleinfertility. Fluid mechanics analysis of the impaired testicular venousdrainage system. Hum. Reprod, 20: 2614-9, 2005.

9- ZAIN BADAR, MICHAEL RACHUN, ZERWA FAROOQ, MEGAN CALABRESE, ANTHONY MOHAMED and MOHAMMED JAWED: Varicocele embolization following failure of varicocelectomy: A case series and review ofliterature., J. Ayub Med. Coll. Abbottabad, 28 (4), 2016.

10-NABI G., ASTERLINGS S., GREENE D.R. and MARSH R.L.: Percutaneous embolization of varicoceles: Outcomes and correlation of semen improvement with pregnancy, Urology, Feb., 63 (2): 359-63, 2004. 


\section{معدل نجاح حقن دوالى الخصية الجهة اليسرى المرتجعة بعد الجراحة دوالح من خلالحل القسطرة}

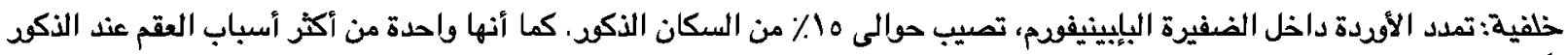

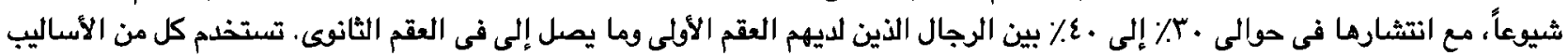

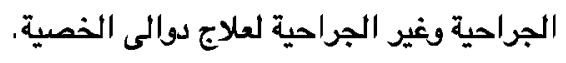

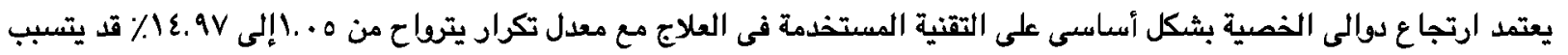

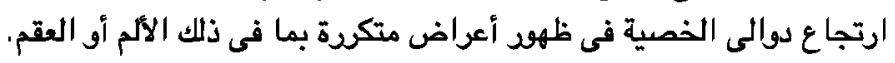

أحد أسباب الفثل الجراحى وجود وصلات وديدية مع وديد الخصية والتى تسبب تكرار دوالى الخصية وعودتها مرة أخرى.

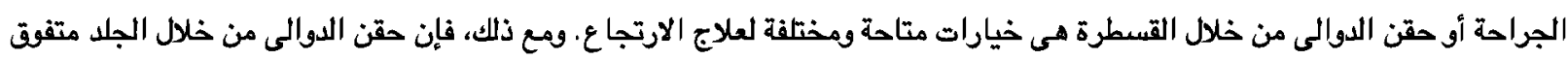
على الجراحة لأنه يمكن تصديد متفيرات وأشكال الأوردة المختلة بالاضافة إلى تصديد أى وصلات وديدية أخرى.

يعد تصوير الأوردة أثناء حقن دوالى الخصية من خلال القسطرة أمراً ضرورياً لتحديد هذه الوصلات الوريدية وغلقها بنجاح. الهدف من العمل: الغرض من هذه الدراسة هو قياس معدل نجاح علاج دوالى الخصية بالجهة اليسرى المرتجعة بعد الجراحة بإستخدام

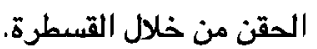

المرضى والطرق: شملت هذه الدراسة 10 مريضاً يعانون من ارتجاع أعراض دوالى الخصية اليسرى (ألم أو العقم) بعد الجراحة. النتائج: نسبة نجاح حقن دوالى الخصية اليسرى المرتجعة بعد الجراحة بإستخدام الحقن من خلال القسطرة يصل إلى ؟بوج٪.

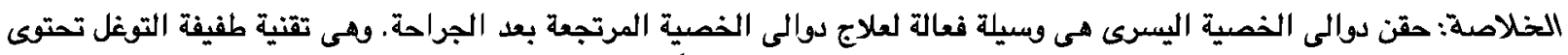

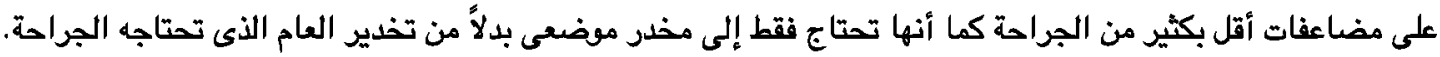

